\title{
Swimming Backstroke Using Aqua Noodle
}

\author{
Ani Pristiawati*, Sriningsih Sriningsih \\ STKIP Pasundan \\ Cimahi, Indonesia \\ *aniendapristia@yahoo.co.id
}

\begin{abstract}
The purpose of this study was to determine the effect of aqua noodle media on backstroke swimming skills. Population and sample of research are male and female student counted 30 people using total sampling technique. The experimental method with one group pre-test post-test design. The results showed that aqua noodle media had an influence on the mastery of backstroke swimming skills. There are several other factors that influence among others is the formation, confidence, and motivation.
\end{abstract}

Keywords: aqua noodle, backstroke, swimming

\section{INTRODUCTION}

One of the aquatic branches that are becoming popular among the people today. Children to adults simply love sports that show the style of swimming with a swimming style. In fact, swimming is often reported as the most common recreational activity among children, with more than 16 million participants every year [1]. Swimming is considered a physical activity with a very beneficial effect on body development, from the process of general growth, hardening and strengthening the body's resistance and increasing the overall capacity of the effort [2]. Aqua noodle is a tool used in the learning process. This tool does not use buoys or assistive devices in other rooms, which is higher than the level of mastery of techniques that will be more easily achieved [3]. By using this tool, you can help lifestyle mastery among students. Maximizing the use of media, especially aqua noodle, will be one of the latest breakthroughs in swimming learning, coaches and athletes can work together to make the time and performance of their motion techniques effective. The media develops new interests, leisure time skills, offering new choices for entertainment and culture in the busy environment of school children [4]. Thus it will be the starting point that the use of media is very useful to produce positive results.

Backstroke is one of the styles learned in schools, from junior high school to college. In universities, especially physical and recreational physical education study programs, all students are required to master the basic backstroke swimming technique in the first semester of college. This is to create students who are ready to accept the challenges in the global era and are able to defend themselves while in the water. Because backstroke is one of the styles for rescue under certain conditions. The air that is inhaled when swimming backstroke is maximal compared to other styles, this is because the body's back style faces face up so that when swimming can freely breathe air. There is little information in the literature describing the oxygen demand of backstroke swimming in highly proficient swimmers [5]. Could aid in both interpretations of oxygen uptake during backstroke in relation to technique-related factors, and interpersonal comparisons of submaximal oxygen costs [6].

\section{METHOD}

The sample of this study is a student of UKM Aquatic PJKR STKIP Pasundan with a total of approximately 30 people. Divided into two groups at the same level between the control group and the experimental group. Sampling using purposive sampling technique. The purposive sampling technique, also called judgment sampling, is the deliberate choice of information due to the qualities of the informant possesses. It is a non-random technique that does not need underlying theories or a set number of informants. Simply put, the researcher decides what needs to be known and sets out. This research method is an experimental method. Experimental research can be interpreted as research which involves manipulation of the condition of the subject under study, accompanied by strict control of external factors and involving comparative subjects or systematic scientific methods that are carried out to establish relationships involving causal phenomena [1]. The research design is the control group pretest-posttest design. The following is a mapping of research design.

TABLE I. Two Group Pretest-PostTeSt Design

\begin{tabular}{|l|l|l|l|}
\hline \multicolumn{1}{|c|}{ Group } & Pre-test & \multicolumn{1}{c|}{ Treatment } & Post-test \\
\hline Eksperiment & $\mathrm{O}_{1}$ & $\mathrm{X}$ & $\mathrm{O}_{2}$ \\
\hline Control & $\mathrm{O}_{1}$ & - & $\mathrm{O}_{2}$ \\
\hline
\end{tabular}

Information:

$\mathrm{O} 1$ : Initial test of backstroke

$\mathrm{X}$ : Learning using the aqua noodle

$\mathrm{O} 2$ : The final test of backstroke.

\section{RESUltS AND DisCUSSION}

TABLE II. CALCULATING THE STANDARD DEVIATION

\begin{tabular}{|c|l|l|l|}
\hline \multicolumn{1}{|c|}{ Group } & \multicolumn{1}{|c|}{ Test period } & \multicolumn{1}{c|}{ Average } & $\begin{array}{c}\text { Standard } \\
\text { deviation }\end{array}$ \\
\hline \multirow{3}{*}{ Group A } & Initial test & 25,5 & 3,36 \\
\cline { 2 - 4 } & Final test & 30,8 & 4,49 \\
\hline
\end{tabular}


realized in the water with the help of the arms and legs $[8,9]$. A media or aqua noodle is very supportive in training or learning [10,11]. Learning media in general is a tool for teaching and learning processes that are very helpful to open up insights and demand that students are able to be creative in stimulating thoughts about the use of learning media. Learning media can also be interpreted as a tool or means or intermediary used in the ongoing interaction process between the teacher and students to encourage the teaching and learning process with the aim of gaining knowledge, skills and strengthening what is learned and helping to achieve quality learning goals. The characteristics and capabilities of each media need to be addressed by the teacher so that they can choose which media suit the conditions and needs [12]. This is because the media acts as a learning stimulant and can foster learning motivation so that students are not easily bored following the teaching and learning process [13].

\section{CONCLUSIONS}

From the discussion that has been raised about swimming backstroke using aqua noodle the author gives the conclusion that, swimming using aqua noodle provides a positive response to improve swimming ability for beginners in backstroke swimming. Swimming using aqua noodle also becomes significant in increasing swimming style for beginners. By referring to the conclusions in this study, the author suggests the teacher or swimming trainer to apply the use of aqua noodle in the training process and in the learning process. Practically, students learn various kinds of learning media used in swimming learning, especially in backstroke swimming and are expected to be able to use the media optimally so as to facilitate learning. Hopefully with this research, researchers and writers will find another learning media that is more varied and innovative.

\section{ACKNOWLEDGMENT}

Thank you very much for Miss. Sriningsih, M.Pd, and all student team of UKM AQUATIC PJKR STKIP Pasundan has supported this research. I hope to do innovative research and provide fresh insight to its readers

\section{REFERENCES}

[1] P. Guys Wet Nicholas and Wounded, "Pediatric facial trauma from swimming and diving" vol. 111, pp. 153-157, 2018.

[2] A. Arsyad, "Media pembelajaran edisi 1," Jakarta, PT. Raha Grafindo Persada, 2002.

[3] Solihin, "Pintar belajar renang dilengkapi CD," Bandung: CV. Alfabeta. p. $41,2016$.

[4] Daniela, "The playful behavior in swimming and its interferences in 1-3 years childs development," vol. 180, pp. 1229 - 1234, 2015.

[5] Ma. Dolores C. Tongco, "Purposive sampling as a tool for informant selection," 2016.

[6] H.K. Smith, " The aerobic demand of backstroke swimming and its relation to body size stroke technique and performance," vol. 58, pp. 182-188.

[7] D. Krause, "Effects of additional knowledge of results on modifying highly practiced acyclic swimming techniques with knowledge of performance," International Journal of Sports Science \& Coaching, vol. 12(6), pp. 737-746, 2017. 
[11] C. Ayán, \& J. Cancela, "Feasibility of 2 different water-based exercise training programs in patients with Parkinson's disease: a pilot study," Archives of physical medicine and rehabilitation, vol. 93(10), pp. 17091714, 2012.

[12] Daryanto, Media Pembelajaran, Yogyakarta, Gavamedia, vol. 25, p. 201.

[13] R. Oxford, \& J. Shearin, "Language learning motivation: Expanding the theoretical framework," The modern language journal, vol. 78(1), pp. $12-28,1994$.

[10] V. N. Irkhin, I. V. Irkhina, T. V. Nikulina, I. N. Nikulin, \& A. P. Peresypkin, "The system of medical and pedagogical support of students' health in the educational process of the university," 2018. 